\title{
TRANSNATIONAL TRANSLATION OF TAIWANESE AND INDONESIAN TRADITIONAL STORIES FOR GLOBAL CITIZENSHIP
}

\author{
Novita Dewi \\ Sanata Dharma University, Indonesia \\ novitadewi@usd.ac.id; novitadewi9@gmail.com \\ DOI: https://doi.org/10.24071/ijhs.2018.010209
}

received 18 December 2017; revised 4 January 2018; accepted 27 February 2018

\begin{abstract}
In order to interact and work with diverse communities in this deeply interconnected world and to help solve such global issues as human rights abuse, ecological damage, economic poverty and extremism, we need to continually recognize and exchange values/perspectives across cultures and boundaries. Border-crossing is a complex but necessary web of interactions and dependencies among nations to create global peace and justice. Taiwan-Indonesia border crossing is insufficient, given that no formal diplomatic relation exists between the two countries excepting the informal such as trade and investment, people-topeople relations, education and popular culture industry. Taiwan and Indonesia similarly shared long history of nationalism, anti-communism, and democratization, but it remains under studied how these historical comparisons are reflected through literature. This paper will argue that transnational translation of literature can connect and define both nations better so as to enhance global connectedness. Thus, the crossing of the cultural boundaries by Taiwanese and Indonesian co-cultures through the translation of diverse literary works may give hope for future development of a mutual, emphatic understanding of each other's cultures.
\end{abstract}

Keywords: transnational, translation, postcolonial, cultural borders

\section{Introduction}

A quick survey on scholarly works on Taiwan and Indonesia reveals that both countries are often discussed in relation to other Asian countries in diverse fields such as education (Fraser \& Goh, 2003), psychology (Shaw et al., 2011), economics (Boddy, 2007) and sciences (Toledo et al, 2006), to mention some. Studies mainly focusing on Taiwan-Indonesia relationship is hard to find. Due to the One China Policy, Taiwan and Indonesia have no formal diplomatic relations although international relations do occur between people. To quote Professor Samuel C. Y. Ku when giving his keynote speech in one international seminar held in Indonesia in 2016, "people are the foundation of all countries" with which people-to-people relations need to be maintained (Heriyanto, 2016). This article would argue that the crossing of the cultural boundaries by Taiwanese and 
Indonesian co-cultures through translation may give hope for future development of a mutual, emphatic understanding of each other's cultures.

\section{Theory}

Following Fairclough \& Wodak (1997), language is ideological, and it constructs reality (Kramsch, 2006) with which the more diverse societies nowadays have to to be more aware of the many, differently conceived, realities. Communication breakdown, misunderstandings and prejudice may occur between, for instance, Taiwan and Indonesia, should people mishandle language to convey reality. Speaking of the crisis of institutionalized religions as seen in the increase of violence and extremism today, Frunză (2011), for instance, highlights that communication constructs reality. He argues further that the globalized postmodern society often fail to communicate openly about new forms of religiosity within the inevitable advances of ICT and globalization of mass culture. Media failing to communicate the language of religion, misunderstanding of religious texts, lacks of interfaith respects are among the many indications of the incapability of language to function properly. Similar to Frunză, Christians (2005) claims that media communication ethics should take into account local knowledge and identities rather than solely use Western references amid this century's rapid globalization of communications. Innovation, collaboration, and intercultural skills therefore have all become increasingly important so as to interpret the various realities, if one wants to become a member of global citizens fostering peace and justice in this interlocked world.

One among the many ways to create global peace and justice is to promote understanding through transnational translation of literature. Literature both connects and defines a nation and the translation thereof fosters global connectedness. Indonesia and Taiwan, for example, similarly shared long history of nationalism, anti-communism and democratization, but it remains under studied how these historical comparison is reflected, much less through literature. It is important therefore to translate as many national literatures as possible into three languages (Indonesian, Chinese, and English) and its cultural, socioeconomic and political implications. The three languages have increasingly become lingua franca for countries in Southeast Asian region. The impact of worldwide spread of trilingual literary texts is thus not difficult to imagine. The availability of such texts to a broad audience will be significant for studies in the humanities in general as well as language and literature in particular within the context of today's global citizenship.

Mindful of the asymmetry of the East-West power-relations and the hegemony of English as global language, translation of literary works in the likes of Taiwanese and Indonesian literatures is never simple but ideologically loaded. It is important to discuss first the concept of translation that has been revisited in postcolonial context. It was Lefevere (1992) and Tymoczko (1999) who argued earlier on that translation is often framed, Eurocentric, ideologically manipulated as usually shown in the translation of non-Western texts into English used globally. Both Lefevere and Tymoczko suggest that translation articulates the voice and stance of the translator whilst taking into account its relevance to the target audience. Building on the previous studies on postcolonial translation, Gentzler (2008) claims that translation is not a secondary process of 
transporting ideas across borders. Translation always involves "primary, primordial and proactive process that continually introduces new ideas, forms or expressions, and pathways for change into cultures" (Gentzler, 2008, p.5). Dismantling the stereotypes of borders, we need to so see borders as opportunities rather than constraints. Translation therefore has to comply the following: (1) Recognition of the global context, (2) Values and perspectives exchanges and (3) Cross-border and cultural understanding articulacy. As said elsewhere, translation is but an interdisciplinary, interlingual and intercultural activity (Dewi, 2016, p.69). It is a negotiation channel for maintaining distinct national identities in global cultural context. This inevitable global-local cultural border-crossing is at the heart of postcolonial translation.

\section{Theory Application}

Data shown by Taipei Economic and Trade Office in Jakarta on TaiwanIndonesia collaborations are increasingly promising in that to a greater extent both countries connect with each other through trade, tourism, education and cultural exchanges. Trade and investment improved significantly especially since the last three years whereby Indonesia becomes Taiwan's $14^{\text {th }}$ largest trading partner in 2016 , the $10^{\text {th }}$ largest source of import for Taiwan and the $16^{\text {th }}$ largest export market. More investments and economic agreements have been signed in recent years (2000s onwards) after its slow beginning in 1990.

Human resource and culture relations however seem slack to emerge, although Indonesian labours in Taiwan is the largest in number and ranked first in Southeast Asia. More educational cooperation and scholarships are available for Indonesian students in Taiwan but the reverse is yet to be seen. Taiwan has lessened the strict immigration law and visa issuance for overseas tourists, but stricter regulations remains enacted to Indonesian citizens. Only (previously) holders of selected dominant countries' visas receive free-entry tourist visa to Taiwan. Nonetheless, the rise of alumnae associations and Taiwanese expatriate clubs in Indonesia is an indication that interconnectedness between the two countries steadily occurs.

Interestingly enough, Taiwanese pop culture has found an easy entrance to Indonesia since a long time. In the 1990s, the Cinderella-like romance novels by Taiwanese-based writer Chiung Yao became a household name in Indonesia. She is known to Indonesian audience when her My Fair Princess was made into television drama series, i.e. the international Asian drama hit Putri Huan Zhu. In the early 2000s, the love lives of Dao Ming Tze and San Cai in the Taiwanese youth drama Meteor Garden were all the rage in Indonesia. The phenomenal success of the series has attracted scholarly attention (e.g. Swastika \& Andari, 2003; Pravitta, 2004; Ida 2008) with regard to the dynamic of urban-youth identities and consumerism in Indonesia. Taiwanese dramas have survived in competition with other television series from India, Korea, Turkey and local soap operas. While no less than 20 Taiwanese dramas are broadcast in Indonesian television, it is important to note that Indonesian-made movies are hardly shown for Taiwanese audience with the exception of the Heart series in Channel 13 Public Television Service. Here we see that the border-crossing is one-directional.

Given the inequality of cultural flows between the two countries, transnational translation with all the complexity and shortcomings (Vatanabadi, 
2009), has to be attempted. This type of translation tasks requires interdisciplinary approach in Postcolonial, Cultural and Translation Studies. Like any existing studies on Taiwan and Indonesia, research in this particular area of translational translation of Taiwanese and Indonesian literary texts is still rare. This present article, however, is preliminary in nature, leaving room for further studies to pick up.

\section{Translating Traditional Stories, Knowing Our Neighbours}

Why traditional stories? Traditional stories reflect the society in which they are told. Despite its often fantastical and larger-than-life nature, traditional tales offer therapeutic effects and positive educational role in increasing personal growth as shown by several studies (e.g. Parkinson, 2009; Ruini et al., 2014; Caracushansky et al., 2016). Such stories provide good sources to disseminate cross-cultural understandings. The transformative power of traditional tales helps promoting global-interconnectivity in multicultural settings.

Taiwan and Indonesia are rich with traditional stories told from age to age to different generations. Like any traditional stories worldwide, moral lessons, truths and wisdoms are encapsulated in Taiwanese and Indonesian enchanting stories. Traditional stories often use popular sayings such as proverbs, metaphors, mottos, aphorisms, etc. to make the accounts easy to remember and ponder their meanings. Literal word-for-word translation does not usually work for, to mention but one, proverbs. In order to achieve idiomatic translation, knowledge about the culture of the source and target languages is important. Some proverbs may have target language equivalences, but the cultural aspects thereof should have similar effects to the ears of the Source Language and the Target Language alike. Although linguistic equivalent in Chinese is available for an Indonesian proverb, for instance, the message of the proverb should be culturally acceptable in Chinese culture.

The traditional Taiwanese story, "Little Frog in the Well", taken from Crystal Dragon of Taiwan website is interesting to discuss in terms of transnational translation. Little Frog adamantly thinks that his own world in the bottom of a deep, dark well is the best. He goes nowhere, drinks the well water, eats insects swirling nearby, and watches the moon and stars at night. He ignores the invitation from the birds that sometimes fly and stop by the well brink to see the outside world. Until one day Yellow Sparrow picks the stubborn frog up and gives him a fly to see many things around him. He sees the blue ocean, mountains, green valleys, apple trees, colourful flowers, monkeys, antelopes, squirrels and many more. He is very happy and now finds a nice place on top of a huge lotus leaf. He stays in the pond and never wants to return to his old, dull well. The Chinese proverb "With a frog in the well you don't talk about the ocean" probably originates from this story to show one's narrow-mindedness.

It would seem that this folktale from Taiwan is culturally shared all over the world. "A frog in the well knows not the ocean" is the equivalent proverb in Japanese. "A man with little learning is like the frog who thinks its pond is an ocean" is a Myanmaran proverb also closer in meaning. Meanwhile, the Indonesian (and also Thai) equivalence is "Frog in a coconut shell." [Katak dalam tempurung]. Still about frog, "The frog wanted to be as big as the elephant and burst" is an Ethiopian proverb that finds its equivalence in the Indonesian "A frog 
wants to be a cow" [Katak hendak jadi lembu]. In Greek, the proverb goes "The frog wanted to be an ox and swelled up until he burst".

Here, the transnational translation of the little frog story as well as its variants should consider its cultural appropriateness. In Taiwan and Japan, most often people see frogs by the wells or ponds, whereas in Indonesia, frogs live in paddy fields, river banks, and other wet places like gutter and ditch. Coconut shells where frogs are usually found hidden in Indonesia and Thailand are hard to find in Taiwan. Here we see that proverbs deal directly with geographical conditions, societal habits and mannerisms unable to translate directly from one society to another. The intended message of the proverb is thus a guide to translate traditional stories like our Little Frog tale. To translate a doubtful literary proverb, suggests Khodorkovsky, look for equivalence within the context of the source culture and the target culture, instead of translating it into a very familiar proverb in the target language.

\section{Conclusion}

Taiwan and Indonesia share hybrid and heterogeneous cultures as a result of similar socio-political and historical experiences. The two countries also share today's global problems. Therefore, they need to continually examine and exchange views across national borders to create better understandings and positive attitudes for the sake of global peace. Aside from strengthening economic partnerships that maybe of more tangible, quantifiable results, augmenting cultural connectivity is equally important by way of, among others, translation of each other's literature in, preferably, three languages. The availability of trilingual literary texts for global audience will be significant for studies in the language, literature and translation in this twentieth century global citizenship. When more and more people interact with each other, the foundation of all countries, to quote Professor Samuel C. Y. Ku again, becomes stronger.

\section{References}

Anonymous. (n.d). Taipei economic and trade office, Jakarta, Indonesia. Retrieved from http://www.roc-taiwan.org/id_en/post/1199.html.

Boddy, C.R. (2007). Projective techniques in Taiwan and Asia-Pacific market research. Qualitative Market Research: An International Journal, 10(1), 48-62.

Caracushansky, S.R,. Antonio, A.C., \& Marechal, R. (2016). The use of myths and fairy tales in a Bernian approach to psychotherapy. Transactional Analysis Journal, 17(1), 277-285. Retrieved from http://dx.doi.org/10.1177/036215378701700104.

Christians, C.G. (2005). Ethical theory in communications research. Journalism Studies, $6(1), \quad 3-14 . \quad$ Retrieved from http://dx.doi.org/10.1080/1461670052000328168.

Crystal Dragon of Taiwan. http://www.cdot.org/links/literature.htm.

Dewi, N. (2016). interface of linguistics, literature, and culture in translating Singapore and Sri Lanka postcolonial poetry. Lingua Cultura, 10(2), 69-75. Retrieved from http://dx.doi.org/10.21512/lc.v10i2.885.

Fairclough, N. \& Wodak, R. (1997). Critical discourse analysis. In T. van Dijk (Ed.), Discourse as social interaction. London: Sage. 
Fraser, B.J. \& Goh, S.C. (2003). International handbook of educational research in the Asia-Pacific region. Berlin: Springer

Frunză, S. (2011). Does communication construct reality? a new perspective on the crisis of religion and the dialectic of the sacred. Revista De Cercetare Şi Intervenţie Socială, 35, 180-193.

Gentzler, E. (2008). Translation and identity in the Americas: New directions in translation theory. London: Routledge.

Heriyanto, D. (2016). People-to-people diplomacy: Foundation of taiwanindonesia relations. The Jakarta Post. Retrieved from http://www.thejakartapost.com/academia/2016/05/13/people-to-peoplediplomacy-foundation-of-taiwan-indonesia-relations.html

Ida, R. (2008). Consuming Taiwanese boys culture: Watching meteor garden with urban kampung women in Indonesia. In A. Heryanto (Ed). Popular culture in Indonesia: fluid identities in post-authoritarian politics. London: Routlede.

Khodorkovsky, M. (2008). How to translate a proverb. ALTA. Retrieved from https://www.altalang.com/beyond-words/2008/11/19/how-to-translate-aproverb/

Kramsch, C. (2006). The multilingual subject. International Journal of Applied Linguistics, 16(1), 97-110.

Lefevere, A. (1992). Translating literature: Practice and theory in a comparative literature context. Modern Language Association of America.

Parkinson, R. (2009). Transforming tales: How stories can change people. London: Jessica Kingsley Publishers.

Pravitta, G.M.M. (2004). Menonton perempuan penonton meteor garden. Clea, 6, $1-29$.

Ruini, C., Masoni,L., Ottolini, F., \& Ferrari, S. (2014). Positive narrative group psychotherapy: The use of traditional fairy tales to enhance psychological well-being and growth. Psychology of Well-Being: Theory, Research and Practice, 4, 13. Retrieved from https://doi.org/10.1186/s13612-013-0013-0.

Shaw, J.D., Jing Z.M. K., Duffy, K.L., Scott, H.S., \& Susanto, E. (2011). A contingency model of conflict and team effectiveness. Journal of applied psychology, 96(2), 391.

Swastika, A. \& Andari, Y. (2003). Meteor mimpi, meteor garden. Retrieved from http://kunci.or.id/teks/12.meteor.html.

Toledo, R., Esteban, J., \& Fried, B. (2006). Immunology and pathology of intestinal trematodes in their definitive hosts. Advances in Parasitology, 63,285-365.

Tymoczko, M. (1999). Post-colonial writing and literary translation. Post-colonial Translation: Theory and Practice, 19-40.

Vatanabadi, S. (2009). Translating the transnational: Teaching the 'other' in translation. Cultural Studies, 23(5\&6), 795-809. Retrieved from https://doi.org/10.1080/09502380903132371 